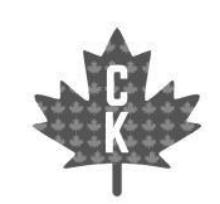

RAVEN LOVERING'

\title{
Graphic Reminders: Confronting Colonialism in Canada through Betty: The Helen Betty Osborne Story
}

\begin{abstract}
David Alexander Robertson's 2015 graphic novel Betty: The Helen Betty Osborne Story connects non-Indigenous Canadians to the racial realities of Canada's intentionally forgotten past. Robertson translates Helen Betty Osborne's biography into the accessible format of the graphic novel which allows for a wide range of readers to connect present day racial injustices to the past, generating new understandings surrounding violence against Indigenous peoples in Canada. Helen Betty Osborne, a young female Cree student was abducted and murdered in 1971, targeted for her race and gender. The horrors Betty experienced reveal the connection between her story and the contemporary narrative of Missing and Murdered Indigenous Women in Canada. Betty: The Helen Betty Osborne Story deconstructs Betty's life from the violence she is subjected to, personifying a historical figure. The graphic novel allows for a visual collision of past and present to express the cycle of colonial violence in Canada ignored by non-Indigenous Canadians despite its continued socio-economic and political impact on Indigenous peoples. As an Indigenous author, Robertson preserves the integrity of Indigenous voice and revives an integral gendered and racialized historical perspective that is necessary to teach. This close reading of Betty: The Helen Betty Osborne Story explores how Robertson uses the graphic novel to revive history and in doing so, demonstrates connections between past and present patterns of racial injustice against Indigenous women in Canada today.
\end{abstract}

Keywords: Colonialism, Canada, Graphic Novels, Indigenous Histories, Missing and Murdered Indigenous Women and Girls; Racism

\section{Résumé}

La bande dessinée romanesque de 2015 de David Alexander Robertson, Betty : The Helen Betty Osborne Story relie les Canadiens non autochtones aux réalités raciales intentionnellement oubliées. Robertson traduit la biographie de Helen Betty Osborne dans le format accessible d'une bande dessinée romanesque qui permet à un grand nombre de lecteurs de relier les injustices raciales actuelles au passé. De plus, elle génère de nouvelles compréhensions entourant la violence contre les peuples autochtones au Canada. Helen Betty Osborne, une jeune étudiante crie, a été enlevée et assassinée en 197I, en raison de sa race et de son sexe. Les horreurs que Betty a vécues révèlent le lien entre son histoire et le récit contemporain des femmes autochtones disparues et assassinées au Canada. Betty : The Helen Betty Osborne Story déconstruit la vie de Betty à partir de la violence qu'elle a subie, personnifiant ainsi une figure historique. La bande dessinée romanesque permet une collision visuelle entre le passé et le présent pour exprimer le cycle de la violence coloniale au Canada, ignoré par les Canadiens non autochtones malgré son impact socio-économique et politique continu sur les peuples autochtones. En tant qu'auteur indigène, Robertson préserve l'intégrité de la voix indigène et fait revivre une perspective historique intégrale, sexuée et racialisée, nécessaire à l'enseignement. Cette lecture attentive de Betty : The Helen Betty Osborne Story explore comment Robertson utilise le roman graphique pour faire revivre l'histoire et, ce faisant, démontre les liens entre les modèles passés et présents d'injustice raciale à l'égard des femmes autochtones au Canada aujourd'hui.

Mots clés: colonialisme, Canada, romans graphiques, histoires des indigènes, les femmes et les filles autochtones disparues et assassinées, le racisme

\footnotetext{
' York University, Ontario.
} 
Interdisciplinary Approaches to Canadian Studies

\begin{abstract}
David Alexander Robertson's 2015 graphic novel Betty: The Helen Betty Osborne Story connects non-Indigenous Canadians to the racial realities of their nation's neglected past and present through the revival of Helen Betty Osborne's illustrated biography. In 1971, Helen Betty Osborne, a nineteen-year-old female Cree student, was abducted and murdered outside of The Pas, Manitoba by four white men (Smulders, 2006). Sixteen years later, only "one of the four men who had abducted her, Dwane Johnston, was convicted and sentenced to life imprisonment...of the other three, one was granted immunity in exchange for his testimony, one was acquitted, and one was never charged" (Smulders, 2006, p. 37). This judiciary negligence (Smulders, 2006) raised questions about the treatment of Indigenous peoples in Canada and the rampant racism-based violence that Indigenous peoples face from non-Indigenous Canadians (Smulders, 2006).
\end{abstract}

Today, Indigenous peoples in Canada continue to experience systemic racism which is enabled by colonial government legislation and socially determined segregation. According to the National Inquiry into Missing and Murdered Indigenous Women and Girls, an estimated 1,200 women and girls have been murdered or gone missing in Canada from 1980 to 2012 (National Inquiry, 2017). Despite this astonishing statistic, "no one knows for sure how many Indigenous women and girls have been murdered or gone missing in Canada" (National Inquiry, 2017, p. 7) as a result of incomplete and racially biased documentation from colonial police forces. Canonical Canadian literature privileges white authorship, neglecting the individual stories and lived experiences of Indigenous women. To have a complete understanding of the history of the land now known as Canada, it is integral to have historical perspectives representative of all peoples, especially intersectional identities that have intentionally and historically been excluded from being formally preserved. I honor the role of David Alexander Robertson, an Indigenous author of Cree heritage, sharing Betty Osborne's story. As a white settler author, I do not intend to speak for Indigenous women, and I acknowledge my inherent biases and privileged position in the close reading of this novel. I intend to examine how Betty: The Helen Betty Osborne Story, uses the format of a graphic novel to connect nonIndigenous Canadians to their intentionally forgotten past, to give a voice to a racialized and gendered historical perspective, and to visually demonstrate connections between past and present patterns of racial injustices against Indigenous women today.

The structure of graphic novels is integral in Robertson's deconstruction of linguistic and cultural barriers between readers and history. Henzi offers that, "this medium of storytelling makes [the] story accessible not only for youth, but for those who may not want to, or cannot, read at length about the history of colonialism" (Henzi, 2016, p. 25). In addition to being a quicker read, the imagery within the graphic novel allows for emotions to be clearly depicted and provides a more attractive way to consume non-fiction literature than through traditional texts (Carleton, 2013).

Henderson's black and white images are fitting in a novel depicting racial segregation creating a division through shading between Indigenous and nonIndigenous bodies, specifically in how hair is depicted. Betty's coloured position on the front cover situates her as the rightful protagonist of her own story, rewriting the details of a collective narrative. Details such as colour and images demonstrate racial segregation in a way only possible in a graphic novel.

Robertson's graphic novel revives Betty's historical perspective and translates her story into simple images and text that can be consumed by a wide audience. Panels with few, or without any words are able to convey an ambiance that spaces in nongraphical I non-fiction texts are unable to achieve. Many graphic novels can be consumed in an hour and the illustrations retain the attention of the reader, inviting them to invest themselves in the story and recognize themselves in the ambiguity of cartoon faces. This ambiguity invokes a stronger connection between readers and characters causing readers to be more likely to understand Betty as a person through the character Robertson creates. Emberley observes, the format of the graphic novel "is largely about re-creating a subject who has been lost to the archive of a collective history" (Emberley, 2014, p. 162). Selective memory is a consequence of colonialism that nonIndigenous Canadians choose when remembering the stories of Indigenous peoples. Time erodes the significance of individual stories, enabling them to blend and form a single narrative perpetuated by dominant ideologies. By translating Betty's historical story into the present, Robertson reminds nonIndigenous Canadians of the relevance of Indigenous stories regardless of their age. Betty: The Helen Betty Osborne Story re-creates how historical perspectives can be understood by using the medium of a graphic novel to allow Canadians to access the importance of individual stories, especially from the historical perspective of an Indigenous woman.

Literature's potential to incite political connections between the past and present is demonstrated when a young boy, in the present, uses the social media platform Facebook to access news articles about Missing and Murdered Indigenous Women and Girls. Both Facebook and graphic novels work to transform text and images into accessible visual stories that can be shared, often, on an international scale. Henderson's illustration shows an article about "Amanda Sinclair" (Robertson \& Henderson, 2015, p. 1) originating from a page titled "Missing Manitoba Women" (Robertson \& Henderson, 
Interdisciplinary Approaches to Canadian Studies

2015, p. 1). The article is shared by a user whose profile picture is an infinity symbol who comments on the Facebook post, "is it just me, or do these come up, like, every freaking day? What the heck?" (Robertson \& Henderson, 2015, p. 1). A seemingly infinite cycle of colonial violence has been occurring against Indigenous women since the colonization of Canada; of which the consequences will continue until collective action and reconciliation are taken. The fourth panel powerfully reflects the face of Amanda Sinclair in the eye of the young boy, showing how history can be understood in the present through the connecting force of literature. Canadians that are not directly affected by issues concerning Indigenous populations are conditioned to ignore or dismiss these issues that they as nonIndigenous Canadians have a role in perpetuating.

By creating accessible content for youth to learn about the historical and present-day perspectives of Indigenous women, non-Indigenous Canadians can begin to deconstruct the important individual stories of Missing and Murdered Indigenous Women and Girls. The stories of MMIWGT2S, their families, and loved ones are stories that must be honored, respected, and heard by non-Indigenous Canadians. Understanding Betty's biography through the graphic novel helps to challenge their understanding of Missing and Murdered Indigenous Women and Girls in Canada, showing through Betty's experiences that violence against Indigenous women is both a historical and contemporary issue.

Collective and individual voices collide when the scope of Indigenous women differentially affected by violence is explored on page two as the boy clicks a website titled, "Missing and Murdered Indigenous Women in Canada" (Robertson \& Henderson, 2015, p. 2). The panel consumes an entire page and contains a collage of missing women, who are overwhelming in their number. The women's faces are contained inside individual squares within the panel beneath shadows that conceal their identities while Betty's face is clearly defined to stand out against the rest. As women who are doubly displaced by their race and gender, Indigenous women are often compartmentalized by non-Indigenous authors, categorized based on race and gender stereotypes that do not correlate with the complexity of their identities. As an Indigenous author himself, Robertson's own biases are necessary in preserving the integrity of Betty's story. The social and political issues surrounding the narrative of Missing and Murdered Indigenous Women and Girls in Canada have been reduced to a single story, neglecting to honor the life and individuality of each woman affected. According to the National Inquiry into Missing and Murdered Indigenous Women and Girls, "Indigenous women are 12 times more likely to be murdered or missing than any other women in Canada, and 16 times more likely than Caucasian women" (National Inquiry,
2017, pp. 86-87). Over 1200 women have been abducted and or murdered in Canada (National Inquiry, 2017), yet their stories are underrepresented, historically ignored. By illustrating Betty's life before the violence which took her life, readers are invited to empathize and understand women as individuals as opposed to the statistic they are grouped into. The collage of women combines the importance of individual and collective voice, challenging readers to exchange their understanding of the numeric value of a socio-political issue for an empathetic visualization of the faces of the affected women.

Betty experiences several barriers to accessing education which are a result of historical and contemporary institutional racism in Canada. The 2017 National Inquiry into Missing and Murdered Indigenous Women and Girls states,

For over a century, the central goals of Canada's Aboriginal policy were to eliminate Aboriginal governments; ignore Aboriginal rights; terminate the Treaties; and, through a process of assimilation, cause Aboriginal peoples to cease to exist as distinct legal, social, cultural, religious, and racial entities in Canada. The establishment and operation of residential schools were a central element of this policy, which can best be described as 'cultural genocide' (p. 11).

Betty leaves home to attend "Guy Hill Residential School, 1971" (Robertson \& Henderson, 2015, p. 8:1), and later high school in The Pas, to pursue her dream of becoming a teacher. In addition to the cultural genocide perpetrated by the residential school system in Canada, publicly funded schools in the second half of the twentieth century disproportionately discriminated against Indigenous students, increasing racial barriers and limiting opportunities for Indigenous peoples. Today, Canadian education systems showcase forms of "cultural imperialism" (Kelly, 2012, p. 139) in which white Anglo-settler ideologies are the cultural norms and values racialized students are expected to conform to. Educational frameworks within schools such as streaming racialized students into applied and workplace level courses, adultification of students, unequal disciplinary consequences, and the reproduction of white settler ideologies target Indigenous students. The community a school serves and operates within determines which students are physically able to access it. In order to attend further education, Betty must move to a foreign town where she is subject to both social isolation and cultural assimilation both of which prove to be dangerous but yet her only opportunity for further formal education. Before her departure, Betty says to her sister, "kids shouldn't have to leave home to go to school. When we're teachers, Eva, we'll come back here and make sure they never have to" (Robertson \& Henderson, 
Interdisciplinary Approaches to Canadian Studies

2015, p. 5:2). Most white settler children grow up in close proximity to a publicly funded school where they see themselves represented in the staff. These students are not required to choose between accessing education and living in their community like many Indigenous students have to. During her time spent in The Pas, Betty is targeted by white males for being a young Indigenous female which leads to her abduction, assault, and murder. Betty addresses the potential for educational equity through her aspirations to return home as a teacher, to be the catalyst for educational opportunity in her community. In Canada, schools are institutions that reproduce accepted notions of settler colonialism, and actively discriminate against Indigenous and racialized students in their frameworks and relationships to communities. Historically, residential schools and publicly-funded Canadian schools have been sites of cultural genocide actively working against Indigenous populations, creating racial barriers and limiting opportunities for racialized people.

Unequal power positions illustrated between Betty and the white residents of The Pas are a direct result of cyclical colonial violence in Canada. Henzi argues that the story "provides a glimpse into the values and perspectives prevalent in Canada in the early seventies -insults, segregation, beatings, kidnappings, and rape -that inevitably led to Helen Betty's murder, and the lack of cooperation in pursuing justice" (Henzi, 2016, p. 34). The novel illustrates how gender and race determine social freedom when Betty experiences different liberties than her white male attackers. In the novel, this group of male assaulters consumes alcohol excessively in public spaces while Betty's alcohol consumption is controlled in private spaces, such as the home, by her host mother Mrs. Benson. On page 14, before the men encounter Betty, the men use force to break into a home, dissolving the physical boundaries that allow for safety, foreshadowing their violent tendencies which are accepted as a result of their race and gender. Betty moves between private and public spaces without being noticed by those around her while the men disrupt public spaces without consequence. The Aboriginal Justice Inquiry (AJI) concluded that "Aboriginal women and their children suffer tremendously as victims in contemporary Canadian society. They are the victims of racism, of sexism and unconscionable levels of domestic violence (1:475)" (as cited by Smulders, 2006, p. 37). Betty was murdered on November 13, 1971 (Smulders) by white Canadian men who targeted her on the basis of race and gender. The 2015 novel's revival of the past reminds readers that the violence Betty experiences is a cycle that continues to target Indigenous women today.

Historically, the English language has repeatedly been used as a colloquial tool to 'otherize' cultural groups with mother tongues other than English, which is represented in Betty through the attitudes of Betty's attackers. On page 21, multiple voices exit from the car, but the speakers' faces are not shown to represent the power of a collective voice (Robertson \& Henderson, 2015). According to the National Inquiry into Missing and Murdered Indigenous Women and Girls of 2017, "the Canadian federal government imposed new colonial policies (particularly through the Indian Act) that fractured and displaced Indigenous Nations (National Inquiry, 2017, p. 18). Colonial use of English as a weapon threatens assimilation and the erasure of different nation's distinct cultures and languages. Legally, the Canadian government has used the Indian Act to displace and devalue Indigenous peoples in Canada which the attackers voices from the car parallel by using derogatory racial slurs to describe Indigenous females. The voices from the car say, "those Indians are always good for it” (Robertson \& Henderson, 2015, p. 21:3). The National Inquiry also explains that "the term 'Indian' is generally considered to be offensive. However, it retains legal meaning within Canadian Legislation" (National Inquiry, 2017, p. 40). Legal language acts as a barrier for people who do not receive a legal education, and the continued acceptance of the Indian Act itself, which legally excuses the cultural genocide of Indigenous peoples, and provides power to the colonial Canadian government through the origins of the name of the Act. In unequal power dynamics, language is a tool weaponized to repress cultural groups based on social hierarchies determined by settler colonialism. The laws that segregate Indigenous peoples use the term "Indian", and this language which is in practice today can be traced to the past legislations put into place with the intent of erasing Indigenous peoples. The use of the term "Indian" today to name legislation concerning Indigenous populations allows the federal government to discriminate against Indigenous people on unceded land which illuminates the continued institutional racism that Canada upholds and refuses to change. Legally and socially, the language used by the men who murder Betty, and our Canadian government, actively work against Indigenous peoples.

Betty: The Helen Betty Osborne Story provides an accessible connection to the past that readers can use to understand present-day racial injustices in Canada. Carleton argues, "comic books that examine racism can play an important role in confronting Canada's racial amnesia and developing peoples' awareness about its harmful effects" (Carleton, 2013, p. 522). Betty's story challenges non-Indigenous Canadian's memory and understanding of racism, the graphic novel reminds them of the consequences of colonial violence that target Indigenous women. On page 30 , the boy virtually shares the article he reads on Facebook about Missing and Murdered Indigenous 
Interdisciplinary Approaches to Canadian Studies

Women (Robertson \& Henderson, 2015). Stories such as Betty's are agents of change and should be translated into accessible mediums such as graphic novels that allow for a broad audience to engage with history in a meaningful way. Empowering Indigenous voices and stories is integral in challenging Canada's racial amnesia and provides opportunities for understanding underrepresented historical perspectives. Betty: The Helen Betty Osborne Story is one of the thousands of individual stories of Indigenous women whose lives are taken because of the acceptance of racist Canadian attitudes and colonial patterns of violence. By illustrating Betty's life before her death, non-Indigenous readers are more likely to understand Betty as a person rather than a statistic that they have become desensitized to because of their privilege. Recognizing Canada's violent past is essential to understanding the identity of the nation that exists today and the experiences of Indigenous peoples who inhabited the land long before colonial settlers. To begin to understand this nation's present and hopeful future, we must look to the past to understand the patterns and consequences of racialized violence.

\section{References}

Carleton, S. (2013). Illustrating Racism: Challenging Canada's Racial Amnesia with Comics. Histoire sociale/Social history 46(92), 509-522. https://www.muse.jhu.edu/article/534571.

Emberley, J. (2014). The testimonial uncanny: indigenous storytelling, knowledge, and reparative practices. SUNY Press.

Henzi, S. (2016). "A Necessary Antidote”: Graphic Novels, Comics, and Indigenous Writing. Canadian Review of Comparative Literature, 43(1), 23-38.

https://doi.org/10.1353/crc.2016.0005

Kelly, D. (2012, Winter). Teaching for social justice: Translating an anti-oppression approach into practice. Our Schools, our Selves, 21, 135-154. Retrieved from http://ezproxy.library.yorku.ca/login?url=http s://www-proquest-

com.ezproxy.library.yorku.ca/magazines/teac hing-social-justice-translatinganti/docview/1035333918/se2?accountid $=15182$

Our Women and Girls are Sacred. (2017). National Inquiry into Missing and Murdered Indigenous Women and Girls.
Robertson, D., \& Henderson, S. (2015). Betty: The Helen Betty Osborne story. HighWater Press.

Smulders, S. (2006). "A Double Assault": The Victimization of Aboriginal Women and Children in "In Search of April Raintree". Mosaic: An Interdisciplinary Critical Journal, 39(2), 37-55. Retrieved January 18, 2021, from http://www.jstor.org/stable/44030185 